Article

\title{
The Perspective of Total Lighting as a Key Factor to Increase the Sustainability of Strategic Activities
}

\author{
Antonio Peña-García ${ }^{1, *(1)}$ and Ferdinando Salata ${ }^{2}(\mathbb{D}$ \\ 1 Dpt. Civil Engineering \& Research Group "Lighting Technology for Safety and Sustainability", \\ University of Granada, 18005 Granada, Spain \\ 2 DIAEE-Area FisicaTecnica, Università degli Studi di Roma "Sapienza", 00184 Roma, Italy; \\ ferdinando.salata@uniroma1.it \\ * Correspondence: pgarcia@ugr.es
}

Received: 17 March 2020; Accepted: 27 March 2020; Published: 1 April 2020

\begin{abstract}
In the last decades, lighting has evolved from a branch of engineering ensuring safety and performance in indoor and outdoor installations, to a key discipline interacting with a wide spectrum of fields and having a deep impact on our daily lives. Although this evolution also applies to other areas of knowledge, the special features of lighting make its potential and also its limitations different. It is not the typical field where a well-established mathematical framework allows a departure from well-defined input and identifying clear effects and conclusions. The reason is that lighting is a field dealing with the interaction between a physical phenomenon and a physiological and psychological system, the human being. In addition to the complexity of its basis, the relationship between lighting and sustainability has become stronger in recent years. This relationship is bi-directional in some cases: on one hand, advanced societies require more and more complex lighting installations, which means high energy consumption, use of raw materials, financial costs, manufacturing and maintenance processes, waste and emissions to the atmosphere. On the other hand, good lighting has an impact on issues like productivity, well-being, happiness, disease avoidance, safety, and many other qualitative aspects whose direct or indirect impact on sustainability is remarkable. This work will analyze how lighting can give answers to questions related to sustainability, not only from the classic topics of energy consumption and waste management, but from a wider and global perspective. The results of these works are analyzed, and the basis of the new framework of total lighting, discussed.
\end{abstract}

Keywords: sustainable lighting; sustainable production; resources; human inducedenvironmental impacts

\section{Introduction}

The relationship between human activity and sustainability is direct and evident in some cases, and more complex in others. It also happens that the environmental impact of some factors directly linked to development has been always considered as negative. Hence, Governments and international bodies have found themselves in the unpleasant diatribe of deciding between development and protection of the environment. The reason is that, except some limited cases, a higher development has been considered as a source of pollution, waste, excessive use of raw materials and, in summary, unsustainability. However, there is an increasing number of studies pointing out that a smart perspective in some fields can not only have a lower direct impact on the environment, but also become a tool to foster sustainable development and even decrease the impact of other human activities. This is the case for lighting. A too straightforward conception of lighting could lead authorities, engineers, and particulars to focus on making it more sustainable through introduction of more efficient light sources and technologies [1-4], decrease of illumination levels and light 
pollution [5-9], and optimization of lighting installations [10-13]. That is what we have classically called "sustainable lighting". However, it is becoming more and more evident that some kinds of lighting can directly contribute to the increase of the agricultural production $[14,15]$, the preservation of cultural heritage [16,17], or the attachment to traditional livelihoods [18], among others.

These and other impacts of a smart lighting can help to decrease massive migrations from rural zones to big cities, contribute to a fair distribution of goods, preserve traditional ways of life, improve the health and well-being of people, and many other effects directly impacting on the environment and allowing development in accordance with the Sustainable Development Goals (SDG) [19]. These less conventional uses with a deep impact on so many aspects of human life constitute what we could call "lighting for sustainability".

In this work, the current situation and perspectives when joining together "sustainable lighting" and "lighting for sustainability" in the global concept of "total lighting", a key factor to foster sustainable development $[20,21]$ will be presented, and the implications for future research analyzed.

\section{Non-Conventional Uses of Lighting}

Research using lighting as a tool to decrease the environmental impact whilst enabling sustainable development has been increasing in recent years. It has specifically focused on some fields: agriculture and cattle, cultural heritage, human productivity, and health and well-being. These fields and others still to be explored are important pillars of more sustainable perspectives of economy, like the one based on circularity and design for use beyond life.

Concerning agriculture, the effects of lighting on the growth and maturation of different vegetable species have been known for ages, but the application of the techniques of illumination, including different wavelengths [14,22], illuminance levels, and combination of sunlight with artificial light has not been considered as a part of a global philosophy of lighting seeking multi-approach to sustainable development. Furthermore, interesting proposals combining the shadowing of greenhouses with electrical production have been possible thanks to the use of solar panels on the crops [15]. As a result of these and other advances, a smart application of lighting allows an increase in land productivity without higher consumption and emissions and even achieving extra energy. Regarding vegetation and lighting from other perspectives and purposes, it has also been found that plantation in certain strategic locations, like portal gates of road tunnels, creates a synergy between the decrease in the environmental impact of the tunnel lighting installation and mountain forestation [23,24].

The situation is similar in cattle and animal production, where energy consumption has been traditionally very high and all the actions to increase sustainability could seem focused on decreasing such consumption. However, some research has demonstrated that accurate lighting can also increase productivity in animal farming without environmental impact.

As pointed out by von Wachenfelt et al. [25], increased photoperiod increases food intake in growing pigs. Interesting research on the results of lighting strategies in farming, especially those involving sunlight, can be found in other works dealing with pig farming [26,27]. In addition, the other main contributors to meat production, chicken and cows, are also affected by lighting conditions. In the case of cow farming, the productivity also affects milk production. Some interesting studies demonstrated a long time ago that supplementary light increased milk yield [28], but today, we also know that certain lighting conditions can also avoid some diseases in cows [29], which means important savings in drugs, loss of production, profit from meat and, in summary, more sustainable cow ranching. Concerning chickens, an accurate period of light exposure also impacts the circadian rhythms, with a subsequent increase in growth and positive impact without higher environmental impact [30,31].

In the case of cultural heritage, rehabilitation, aesthetic impact, and the subsequent attachment to the homeland in many underdeveloped countries, strongly depend on an accurate lighting. The very interesting work of Martin Sibley and Magda Sybley [32] demonstrated that "the combination of the vernacular natural lighting system, and a high-tech small scale solar powered electric lighting system 
allowed the development of a sensitive and non-intrusive solution" in the more than 4000 public traditional Moroccan "hammams".

Other interesting works have departed from lighting to provide new perspectives of cultural heritage, its rehabilitation and use. For example, lighting provided Almodovar-Melendo, Cabeza-Lainezm and Rodriguez-Cunill with a tool to carry out one analysis of one of the most beautiful and most visited catholic churches in the south of Spain [16]. In addition, some of these authors also used lighting-based considerations to study the sustainability of some specific historic buildings in Asian countries like India, Korea, and China [17]. These references are a worthy example of the versatility of lighting: whereas cultural heritage in western countries like Spain is a source of income (and sometimes a danger for its correct conservation), in other countries, like those included in [17], it can be also a key factor to strength the attachment of people to their homelands, the rural media, etc. The attachment to some given regions is very relevant when considering migration, especially uncontrolled migration from the countryside to big cities, whose impact on the agriculture is very negative. In addition, uncontrolled migration to big cities in many countries in Asia, Africa, and South America result in big groups of migrants with low-qualified works, poverty, overcrowding, and the use of non-sustainable resources like coal, diesel, or kerosene.

It is interesting to remark that certain kinds of lighting, like the one based on burning kerosene, are sources of very high emissions of black carbon (around 3\% of the total, according to [33]) and other hazardous substances. The environmental impact of these sources goes beyond carbon emissions, but also has indirect environmental impacts due to the proven negative effects on health [34], quality of life, aging, and future needs of people. This is especially important in the countries where those light sources are most widely used due to their difficulty affording long-term solutions that can ensure people's well-being. Given the intensive use of kerosene wick lamps in developing countries where access to electricity is not always granted, implementation of new lighting technologies, like Light-Emitting Diodes (LED) powered by solar panels or similar, can result in a very remarkable decrease in the environmental impact and a boost to disease prevention.

However, the impact of lighting does not concern human health and well-being only from the perspective of diseases caused by emissions and contamination: in addition, physical and psychological well-being are targets whose importance is increasing every day. However, the difficulty to quantitatively measure the degree of well-being is not a minor obstacle. For this reason, qualitative tools like surveys and others are nowadays habitual tools in lighting almost at the same level as luxmeters or other instruments. In the line of the "lighting for sustainability" that promotes this work, this search for well-being must also be accompanied by a decrease in its environmental impact.

Hence, recent research relating a smart use of the spectral distribution and correlated color temperature of the emitted light in indoor lighting with the perceived temperature indicates the way to save energy from HVAC (heating, ventilation, and air conditioning) installations whilst ensuring the well-being of their users [35]. Other research has focused on people's recovery from sickness [36,37], traumatic experiences [38], and even on the prevention of such traumatic experiences [39]. We consider that these large amounts of impacts of certain kinds of lighting on human conditions can be grouped as health and well-being-related impacts of smart lighting, which, in all these cases, has an important environmental impact due to complex therapies and other factors.

Another important effect of smart lighting on sustainable development without worsening environmental impact is the increase of productivity in human activities [40], particularly factories [41] and office environments [42]. The economic benefits arising from these productive philosophies are an objective of many matters currently developing within the framework of circular economy, whose coupling with lighting is really fruitful, as shown in several studies to date [43-45].

At first glance, it could seem that all the uses of lighting described above conform an inhomogeneous and messy matter without any coherence. A field where anything could be eventually taken or disregarded according to our convenience. However, a deep reflection on these applications 
shows that, precisely, they make lighting a deeply coherent field where a global perspective can create synergies of general application.

In addition, the analysis of the effects of carefully designed lighting can give a precise idea about how promising the applications of lighting to decrease the environmental impact and settle the path towards a really sustainable development are.

In the next section, some considerations and conclusions on the role of total lighting, a very recent concept $[20,21]$, considering lighting as a global and transversal discipline, will be analyzed and presented.

\section{Total Lighting}

Some years ago, the net savings in installed power (e.g., consumption per luminary, number of luminaries, and electrical auxiliary devices) and the net economical investment were the main targets for sustainable lighting installations. Currently, however, the concept of "sustainable lighting installation" transcends energetic and economic considerations and has been extended to areas as diverse as user well-being, long-term effects on health and environment, cultural heritage, access to food and education, as well as many other aspects that enrich the modern vision of "sustainability". In recent years (which have been even fewer in certain countries) and especially after the Brundtland report, sustainability has acquired a more far-reaching significance and pursues a development geared to "meet the needs of current generations without compromising the ability of future generations to meet their own needs".

When reflecting on this evolution, the following question arises: where is the inflection-point between traditional uses of lighting, mainly focused to enable human activity while preserving safety of people and goods, and some other uses currently assisting mankind in unexpected aspects?

There have been several facts that could answer to this question. They go from the adoption of a broader concept of sustainability, to the breaking discoveries that enabled a real (although not still complete) understanding of the non-visual paths and their effects on human activities [46-48].

As a consequence, we are now in a scenario where the impact of lighting on sustainability can be decreased through a careful design of installations, in what we can call "sustainable lighting". However, the most impacting novelty is the use of lighting to make many human activities more sustainable. This is what could be called "lighting for sustainability". The union of both concepts is what we call "total lighting" [20,21].

Figure 1 shows the role of total lighting as a union of "sustainable lighting" and "lighting for sustainability" as key global player:

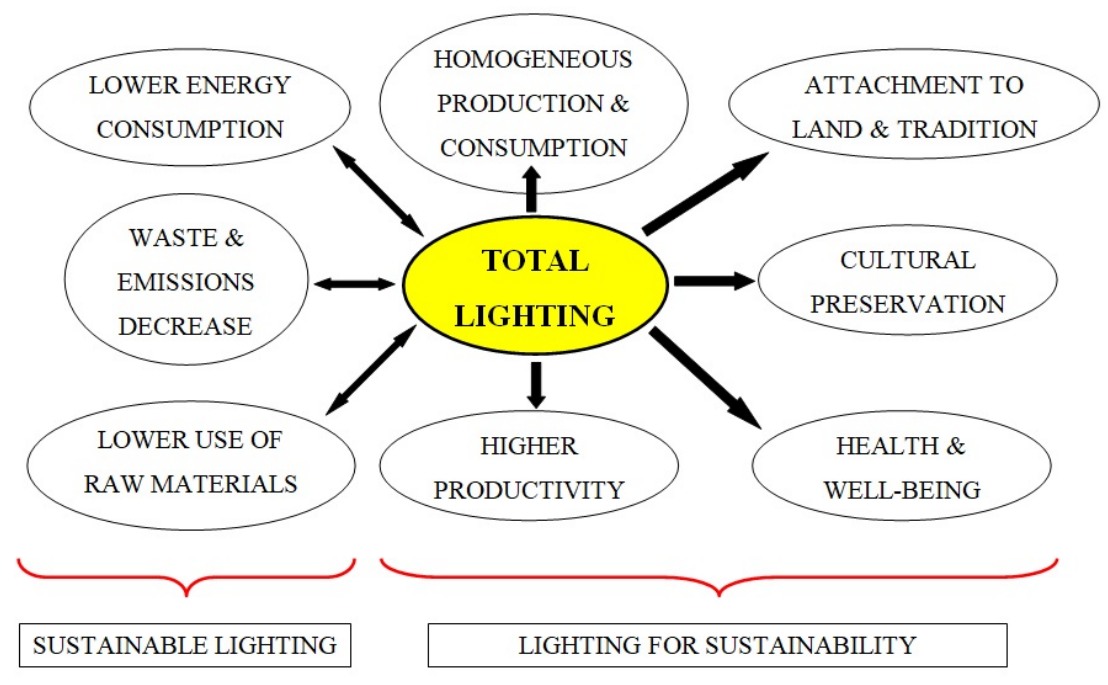

Figure 1. Total lighting and its impacts on different strategic areas. Note the bi-directional relationship with the classical areas related to consumption and waste decrease. 
To approach this concept, we must change our understanding of lighting and start to understand it as a general discipline spreading over all the aspects of human life beyond the classical uses to increase safety with the lowest consumption. Thus, the traditional understanding of lighting must evolve towards total lighting [20,21].

\section{Discussion and Conclusions}

After many years exclusively focused on the safety of people and goods, the decrease in energy consumption for the sake of a more sustainable way of life became a key target for lighting. However, in recent years a complementary trend has been gaining force: the conception of light not only as a field whose environmental impact must be decreased, but as a key tool to decrease the environmental impact and make other human activities more sustainable. This role of lighting is in some cases unexpected and, in many others, a field of intensive research whose conclusions should be seriously considered by public administrations, international organizations, and rule-making bodies around the world.

The current achievements in the matter of agriculture, farming, preservation of cultural heritage, attachment to homelands through the preservation of traditional culture and economical activities, the increase of productivity without additional consumption or environmental impact, and many other essential aspects in the current world, are related to each other by carefully planned and designed lighting installations for each situation and the needs of the final users. Furthermore, recent basic discoveries, like the way the non-visual paths of melatonin, cortisol, and others work, are in the very basis of some of the abovementioned achievements.

In spite of the evidence presented in this work, the concept of "total lighting", including the not very familiar perspective of "lighting for sustainability", is not an exact recipe whose application can always decrease environmental impact and increase the sustainability in the activities where it is applied. Instead, the needed "smart lighting" to be applied in each case depends on the activity under consideration and cannot always be generalized for a wide range of fields.

Thus, the spectral distribution and illuminance level of lighting to increase the growth of certain vegetal species is quite different from those needed for factory employees to manufacture more pieces per hour; the lighting in rural areas to protect them from light pollution is not always the most accurate to ensure a good equilibrium between all the species in that habitat; the productivity in one factory is not only a function of the lighting conditions, but a sum of factors remarkably modulated by the illumination.

In summary, we are entering the era when lighting, in addition to decreasing its environmental impact, is becoming a tool for other activities to actually decrease it. It is the era of total lighting. More research and education at all levels will show us the next milestones in a future that is expected to be very bright.

Author Contributions: Conceptualization, A.P.-G.; methodology, F.S.; A.P.-G. and F.S.; resources, A.P.-G.; writing - original draft preparation, A.P.-G. and F.S.; funding acquisition, A.P.-G. All authors have read and agreed to the published version of the manuscript.

Funding: This research received no external funding.

Conflicts of Interest: The authors declare no conflict of interest.

\section{References}

1. Montoya, F.G.; Peña-García, A.; Juaidi, A.; Manzano-Agugliaro, F. Indoor Lighting Techniques: An overview of evolution and new trends for energy saving. Energy Build. 2017, 140, 50-60. [CrossRef]

2. Singh, D.; Nishal, V.; Bhagwan, S.; Saini, R.K.; Singh, I. Electroluminescent materials: Metal complexes of 8-hydroxyquinoline-A review. Mater. Des. 2018, 156, 215-228. [CrossRef]

3. ur Rahman, T.; Raza, S.; Saeed, M.; Jameel, S. An Emerging White LED Technology and associated Thermal Issues-A Review. J. Appl. Emerg. Sci. 2019, 9, 106. 
4. Chen, W.; Fan, J.; Qian, C.; Pu, B.; Fan, X.; Zhang, G. Reliability Assessment of Light-Emitting Diode Packages with Both Luminous Flux Response Surface Model and Spectral Power Distribution Method. IEEE Access 2019, 7, 68495-68502. [CrossRef]

5. Rabaza, O.; Aznar-Dols, F.; Mercado-Vargas, M.; Espín-Estrella, A. A new method of measuring and monitoring light pollution in the night sky. Lighting Res. Technol. 2014, 46, 5-19. [CrossRef]

6. Peña-García, A.; Sedziwy, A. Optimizing lighting of rural roads and protected areas with white light: A compromise among light pollution, energy saving and visibility. Leukos 2020, 16, 147-156. [CrossRef]

7. Tabaka, P.; Fryc, I. Landscape Lighting as a Source of Light Pollution-The Effect of the Seasons on This Phenomenon. In Proceedings of the Conference: 2016 IEEE Lighting Conference of the Visegrad Countries (Lumen V4), Karpacz, Poland, 13-16 September 2016.

8. Rabaza, O.; Gómez-Lorente, D.; Pérez-Ocón, F.; Peña-García, A. A simple and accurate model for the design of public lighting with energy efficiency functions based on regression analysis. Energy 2016, 107, 831-842. [CrossRef]

9. Schroer, S.; Huggins, B.J.; Azam, C.; Hölker, F. Working with Inadequate Tools: Legislative Shortcomings in Protection against Ecological Effects of Artificial Light at Night. Sustainability 2020, 12, 2551. [CrossRef]

10. Sedziwy, A. A new approach to street lighting design. Leukos 2016, 12, 151-162. [CrossRef]

11. Kostic, M.; Djokic, L. Recommendations for energy efficient and visually acceptable street lighting. Energy 2009, 34, 1565-1572. [CrossRef]

12. Kostic, M.; Djokic, L.; Pojatar, D.; Strbac-Hadzibegovic, N. Technical and economicanalysis of road lighting solutions based on mesopic vision. Build. Environ. 2009, 44, 66-75. [CrossRef]

13. Ocana-Miguel, A.; Andres-Diaz, J.R.; Hermoso-Orzáez, M.J.; Gago-Calderón, A. Analysis of the viability of street light programming using commutation cycles in the power line. Sustainability 2018, 10, 4043. [CrossRef]

14. Garcia-Caparros, P.; Chica, R.; Almansa, E.; Rull, A.; Rivas, L.; García-Buendía, A.; Barbero, F.; Lao, M. Comparisons of Different Lighting Systems for Horticultural Seedling Production Aimed at Energy Saving. Sustainability 2018, 10, 3351. [CrossRef]

15. Aroca-Delgado, R.; Pérez-Alonso, J.; Callejón-Ferre, A.; Velázquez-Martí, B. Compatibility between Crops and Solar Panels: An Overview from Shading Systems. Sustainability 2018, 10, 743. [CrossRef]

16. Almodovar-Melendo, J.; Cabeza-Lainez, J.; Rodriguez-Cunill, I. Lighting Features in Historical Buildings: Scientific Analysis of the Church of Saint Louis of the Frenchmen in Sevilla. Sustainability 2018, 10, 3352. [CrossRef]

17. Salguero Andujar, F.; Rodriguez-Cunill, I.; Cabeza-Lainez, J. The Problem of Lighting in Underground Domes, Vaults, and Tunnel-Like Structures of Antiquity; An Application to the Sustainability of Prominent Asian Heritage (India, Korea, China). Sustainability 2019, 11, 5865. [CrossRef]

18. Nguyen, T.P.L.; Peña-García, A. Users' Awareness, Attitudes, and Perceptions of Health Risks Associated with Excessive Lighting in Night Markets: Policy Implications for Sustainable Development. Sustainability 2019, 11, 6091. [CrossRef]

19. United Nations Division for Sustainable Development Goals (DSDG). Available online: https:// sustainabledevelopment.un.org/ (accessed on 10 March 2020).

20. Peña-García, A. Sustainability as the Key Framework of a Total Lighting. Sustainability 2018, 10, 4412. [CrossRef]

21. Peña-García, A. Towards Total Lighting: Expanding the frontiers of Sustainable Development. Sustainability 2019, 11, 6943. [CrossRef]

22. García-Caparrós, P.; Almansa, E.; Chica, R.; Lao, M. Effects of Artificial Light Treatments on Growth, Mineral Composition, Physiology, and Pigment Concentration in Dieffenbachia maculata "Compacta" Plants. Sustainability 2019, 11, 2867. [CrossRef]

23. López, J.C.; Grindlay, A.L.; Carpio, M.; Peña-García, A. Strategies for the optimization of binomial energy saving landscape integration in road tunnels. In WIT Transactions on Ecology and the Environment; WIT Press: Boston, MA, USA, 2014; Volume 190, pp. 511-520.

24. García-Trenas, T.; López, J.C.; Peña-García, A. Proposal to forest Alpine tunnels surroundings to enhance energy savings from the lighting installations. Towards a standard procedure. Tunn. Undergr. Space Technol. 2018, 78, 1-7. [CrossRef]

25. von Wachenfelt, H.; Vakouli, V.; Pacheco-Diéguez, A.; Gentile, N.; Dubois, M.C.; Jeppsson, K.-H. Lighting Energy Saving with Light Pipe in Farm Animal Production. J. Daylighting 2015, 2, 21-31. [CrossRef] 
26. Pacheco-Diéguez, A.; Gentile, N.; von Wachenfelt, H.; Dubois, M.C. Daylight Utilization with Light Pipe in Farm Animal Production: A Simulation Approach. J. Daylighting 2016, 3, 1-11. [CrossRef]

27. Taylor, N.; Prescott, N.; Perry, G.; Potter, M.; Le Sueur, C.; Wathes, C. Preference of growing pigs for illuminance. Appl. Anim. Behav. Sci. 2006, 96, 19-31. [CrossRef]

28. Peters, R.R.; Chapin, L.T.; Leining, K.B.; Tucker, H.A. Supplemental lighting stimulates growth and lactation in cattle. Science 1978, 199, 911-912. [CrossRef]

29. Penev, T.; Veselin, R.; Slavov, T.; Kirov, V.; Dimov, D.; Atanasoff, A.; Marinov, I. Effect of lighting on the growth, development, behaviour, production and reproduction traits in dairy cows. Int. J. Curr. Microbiol. App. Sci. 2014, 3, 798-810.

30. Huth, J.C.; Archer, G.S. Comparison of Two LED Light Bulbs to a Dimmable CFL and their Effects on Broiler Chicken Growth, Stress, and Fear. Poult Sci. 2015, 94, 2027-2036. [CrossRef]

31. Rogers, A.G.; Pritchett, E.M.; Alphin, R.L.; Brannick, E.M.; Benson, E.R.I. Evaluation of the impact of alternative light technology on male broiler chicken growth, feed conversion, and allometric characteristics. Poult Sci. 2015, 94, 408-414. [CrossRef]

32. Sibley, M.; Sibley, M. Hybrid Green Technologies for Retrofitting Heritage Buildings in North African Medinas: Combining Vernacular and High-tech Solutions for an Innovative Solar Powered Lighting System for Hammam Buildings. Energy Procedia 2013, 42, 718-725. [CrossRef]

33. Lam, N.L.; Chen, Y.; Weyant, C.; Venkataraman, C.; Sadavarte, P.; Johnson, M.A.; Smith, K.R.; Brem, B.T.; Arineitwe, J.; Ellis, J.E.; et al. Household Light Makes Global Heat: High Black Carbon Emissions From Kerosene Wick Lamps. Environ. Sci. Technol. 2012, 46, 13531-13538. [CrossRef]

34. Lam, N.L.; Smith, K.R.; Gauthier, A.; Bates, M.N. Kerosene: A review of household uses and their hazards in low- and middle-income countries. J. Toxicol. Environ. Health. B Crit. Rev. 2012, 15, 396-432. [CrossRef] [PubMed]

35. Golasi, I.; Salata, F.; de Lieto Vollaro, E.; Peña-García, A. Influence of lighting colour temperature on indoor thermal perception: A strategy to save energy from the HVAC installations. Energy Build. 2019, 185, 112-122. [CrossRef]

36. Figueiro, M.; Rea, M.S. Tailored lighting intervention to improve sleep in patients with dementia. Sleep Med. 2019, 64, S115. [CrossRef]

37. Figueiro, M.; Plitnick, B.; Roohan, C.; Sahin, L.; Kalsher, M.J.; Rea, M.S. Effects of a Tailored Lighting Intervention on Sleep Quality, Rest-Activity, Mood, and Behavior in Older Adults With Alzheimer Disease and Related Dementias: A Randomized Clinical Trial. J. Clin. Sleep Med. Jcsm Off. Publ. Am. Acad. Sleep Med. 2019, 15, 1757-1767. [CrossRef]

38. Amorim, R.; López, J.C.; Molina-Moreno, V.; Peña-García, A. Use of Natural Light vs. Cold LED Lighting in Installations for the Recovery of Victims of Gender Violence: Impact on Energy Consumption and Victims' Recovery. Sustainability 2017, 9, 562. [CrossRef]

39. Amorim, R.; Molina-Moreno, V.; Peña-García, A. Proposal for Sustainable Dynamic Lighting in Sport Facilities to Decrease Violence among Spectators. Sustainability 2016, 8, 1298. [CrossRef]

40. Dehoff, P. The impact of changing light on the well-being of people at work. In Proceedings of the 5 th European Conference on Energy-Efficient Lighting, Nice, France, 29-31 May 2002; p. 374-351.

41. Juslén, H.; Wouters, M.; Tenner, A. The influence of controllable task-lighting on productivity: A field study in a factory. Appl. Ergon. 2007, 38, 39-44. [CrossRef]

42. Kraneburg, A.; Franke, S.; Methling, R.; Griefahn, B. Effect of color temperature on melatonin production for illumination of working environments. Appl. Ergon. 2017, 58, 446-453. [CrossRef]

43. Molina-Moreno, V.; Leyva-Díaz, J.C.; Sánchez-Molina, J.; Peña-García, A. Proposal to foster sustainability through circular economy-based engineering: A profitable chain from waste management to tunnel lighting. Sustainability 2017, 9, 2229. [CrossRef]

44. Hermoso-Orzáez, M.J.; Lozano-Miralles, J.A.; Lopez-Garcia, R.; Brito, P. Environmental criteria for assessing the competitiveness of public tenders with the replacement of large-scale LEDs in the outdoor lighting of cities as a key element for sustainable development: A case study applied with PROMETHEE methodology. Sustainability 2019, 11, 5982. [CrossRef]

45. Lozano-Miralles, J.A.; Hermoso-Orzáez, M.J.; Gago-Calderón, A.; Brito, P. LCA Case Study to LED Outdoor Luminaries as a Circular Economy Solution to Local Scale. Sustainability 2020, 12, 190. [CrossRef] 
46. Berson, D.M.; Dunn, F.A.; Takao, M. Phototransduction by retinal ganglion cells that set the circadian clock. Science 2002, 295, 1070-1073. [CrossRef] [PubMed]

47. Hattar, S.; Liao, H.W.; Takao, M.; Berson, D.M.; Yau, K.W. Melanopsin-containing retinal ganglion cells: Architecture, projections, and intrinsic photosensitivity. Science 2002, 295, 1065-1070. [CrossRef] [PubMed]

48. Lucas, R.J.; Peirson, S.N.; Berson, D.M.; Brown, T.M.; Copper, H.M.; Czeisler, C.A.; Figueiro, M.G.; Gamlin, P.D.; Lockley, S.W.; O’Hagan, J.B.; et al. Measuring and using light in the melanopsin age. Trends Neurosci. 2014, 37, 1-9. [CrossRef] [PubMed]

(C) 2020 by the authors. Licensee MDPI, Basel, Switzerland. This article is an open access article distributed under the terms and conditions of the Creative Commons Attribution (CC BY) license (http://creativecommons.org/licenses/by/4.0/). 